\title{
Management of basic health units in municipalities of different size: profile and management instruments*
}

\author{
GERÊNCIA DE UNIDADE BÁSICA DE SAÚDE EM MUNICÍPIOS DE DIFERENTES \\ PORTES: PERFIL E INSTRUMENTOS GERENCIAIS UTILIZADOS
}

\section{GERENCIA DE UNIDAD BÁSICA DE SALUD EN MUNICIPIOS DE DISTINTOS PORTES: PERFIL E INSTRUMENTOS DE GESTIÓN UTILIZADOS}

\section{Brígida Gimenez Carvalho', Marina Peduzzi², Elisabete de Fátima Polo de Almeida Nunes³ Fernanda de Souza Leite ${ }^{4}$, Jaqueline Alcântara Marcelino da Silva ${ }^{5}$}

\begin{abstract}
Objective: To identify the characteristics of managers and their use of management instruments in primary care and to analyze differences in these features among municipalities of different sizes. Method: The present cross-sectional descriptive study was conducted at 108 basic health units from 21 municipalities in northern Paraná, Brazil. The data were collected using a semi-structured questionnaire during the second half of 2010. Results: Most managers had graduate degrees and were female and nurses. The managers from the small municipalities were younger, their payment was lower, and they had less work experience. The use of management instruments was expressive for both the organization and work management; however, the instruments were used less in the small municipalities. Conclusion: The managers were committed to their role; it is recommended that policies and guidance should be formulated at the federal and state levels to support small municipalities.
\end{abstract}

\section{DESCRIPTORS}

Nursing

Management

Health Services Administration

Primary Health Care

\section{RESUMO}

Objetivo: Identificar as características dos gerentes, o uso de instrumentos gerenciais na atenção básica e analisar diferenças destes aspectos em municípios de diferentes portes populacionais. Método: Estudo do tipo transversal descritivo, realizado em 108 unidades básicas de saúde de 21 municípios do norte do Paraná, Brasil. Os dados foram coletados por questionário semiestruturado no segundo semestre de 2010. Resultados: A maioria das gerentes era do sexo feminino, enfermeiras e pós-graduadas. Nos pequenos municípios eram mais jovens, tinham menores salários e experiência. O uso de instrumentos gerenciais foi expressivo tanto para a organização como para gestão do trabalho, porém foram menos utilizados nos pequenos municípios. Conclusão: Constatou-se comprometimento da gestão do trabalho e recomenda-se formulação de políticas orientadoras pela esfera federal e estadual em apoio aos pequenos municípios.

\author{
DESCRITORES \\ Enfermagem \\ Gerência \\ Administração de Serviços de Saúde \\ Atenção Primária à Saúde
}

\begin{abstract}
RESUMEN
Objetivo: Identificar las características de los gerentes, el uso de instrumentos de gestión en la atención básica y analizar las diferencias de esos aspectos en municipios de diferentes portes poblacionales. Método: Estudio del tipo transversal descriptivo, realizado en 108 unidades básicas de salud de 21 municipios del norte de Paraná, Brasil. Se recogieron los datos por cuestionario semiestructurado en el segundo semestre de 2010. Resultados: La mayoría de los gerentes era del sexo femenino, enfermeras y postgraduadas. En los pequeños municipios eran más jóvenes, cobraban sueldos más bajos y tenían menos experiencia. El empleo de instrumentos de gestión fue expresivo tanto para la organización como para la gestión laboral, sin embargo fueron menos utilizados en los pequeños municipios. Conclusión: Se constató comprometimiento de la gestión laboral y se recomienda el planteamiento de políticas orientadoras en el marco federal y estatal en apoyo a los pequeños municipios.
\end{abstract}

DESCRIPTORES
Enfermería
Gerencia
Administración de los Servicios de Salud
Atención Primaria de Salud

"Extracted from the Thesis "Coordenação de Unidade na Atenção Básica do SUS: trabalho, interação e conflitos", School of Nursing, University of São Paulo, 2012. ${ }^{1}$ Associate Professor, Department of Public Health, State University of Londrina, Londrina, Paraná, Brazil. ${ }^{2}$ Associate Professor, Department of Professional Counseling, School of Nursing, University of São Paulo, São Paulo, São Paulo, Brazil. ${ }^{3}$ Senior Professor, Graduate Program in Public Health, State University of Londrina, Londrina, Paraná, Brazil. ${ }^{4}$ Resident Nurse, Multidisciplinary Residency Program in Family Health, State University of Londrina, Londrina, Paraná, Brazil. ${ }^{5}$ PhD Student, School of Nursing, University of São Paulo, São Paulo, São Paulo, Brazil. 


\section{INTRODUCTION}

Since the establishment of the Unified Health System (Sistema Único de Saúde - SUS) more than 20 years ago, decentralization, one of its basic organizing principles, has induced changes in managerial habits by introducing new actors into the field. Upon accepting the management of the SUS at the local level, the municipal managers were given several responsibilities, including the planning and funding of actions, administration and control of financial resources, regulation of the full set of healthcare services in the corresponding area, organization of the healthcare flow, and supply of healthcare actions and services ${ }^{(1)}$. To fulfill the intended goals, the managers established a broad-scoped network of primary care services. As a result, whereas the municipalities were in charge of the execution of actions decided at the state and federal levels in earlier times, after the establishment of the SUS, the municipalities became the main planners, executors of healthcare policies and managers of the workforce.

In Brazil, primary care (PC), also called basic care (BC), considered the preferential path of access of the population to SUS services, is in charge of the organization and integration of healthcare networks ${ }^{(2)}$. For BC to accomplish the role attributed to it in Brazil, logistics, including appropriate physical facilities, resources for communication and integration of the various services, and highly qualified professionals, are needed ${ }^{(3)}$. In addition, the Basic Health Units (BHUs) require more autonomy and decision-making power given the organization of the work process, integration with other points within the healthcare network, and management of the workforce (a larger number of workers with greater diversity of professional training), who are no longer seen as mere resources but as social actors needed to change how healthcare work should be performed ${ }^{(4)}$.

Despite the recognition of these needs, the organization of work and management in the healthcare sector remains strongly influenced by the classic Taylor/Ford model of administration and the bureaucratic model. In the performance of their function, managers usually assume the task of controlling and regulating the work performed at healthcare units, which are oriented by scientific management using technical norms and standards $s^{(5-7)}$.

In the present study, the management of $B C$ is approached from the theoretical perspective of the work process in healthcare. It is worth emphasizing that management can be simultaneously understood as an instrument of the work process in healthcare ${ }^{(4)}$ and as a specific managerial work process ${ }^{(8)}$; only the latter view was adopted in the present study as the basis for the analysis of the results.

The specific managerial work process comprises a set of unique and interrelated activities to serve a given purposethe establishment and maintenance of conditions favorable to the implementation of a given healthcare model ${ }^{(8)}$ to provide comprehensive care to users (i.e., to satisfy all the user's healthcare needs). It acts on a given object through pre-defined instruments. The object of managerial intervention is the organization of the work process itself and the workers activities at healthcare units. The instruments of managerial work include various types of knowledge, techniques and technologies, such as planning, sizing, recruiting and selection of the workforce, assessment of performance and service, and healthcare continuing education, among others ${ }^{(8)}$.

Several studies on BC management conducted in Brazil noted some weak points as well as the need for broader-scoped research to identify its potency in work management to contribute to the possible transformation of healthcare services from the perspective of integral and high-quality care ${ }^{(6-11)}$.

The aim of the present study is to look more closely at the healthcare organizations operating at the BC level, with particular focus on the management of services. More particularly, it was sought to identify the characteristics of BHU managers and their use of management instruments was, as was to analyze possible differences in these characteristics between two groups of municipalities: small and medium/large.

\section{METHOD}

The present cross-sectional, descriptive and quantitative study of work process management in the SUS PC network included 21 municipalities corresponding to a single health administration district in northern Paraná State, Brazil.

The municipalities included in the present study were divided into two groups-namely, small and medium/ large-due to the characteristics of each municipality category ${ }^{(12)}$ and due to the difference found in the results. The group of small municipalities included 17 municipalities with less than 20,000 inhabitants, and the other four municipalities, with populations varying from 40,000 to little more than 500,000 inhabitants, were included in the group of medium/large counties.

The study population comprised the managers of the 122 BHUs in the municipalities of the region investigated; $45 \mathrm{BHUs}$ were located in small municipalities and 77 in medium/large municipalities. The inclusion criteria were individuals acting as BHU managers and agreeing to participate in the study; managers who were away at the time of data collection, due to vacation or on leave for any reason, and those who refused participation, were excluded. BHUs without an appointed manager at the time of data collection were also excluded from the study. As a result, the final sample included 108 managers (88.5\%): 36 (80.0\%) from small and 72 (93.5\%) from medium/large municipalities. Fourteen BHUs were excluded (six had no appointed manager; six managers were on vacation or on leave; two managers refused to participate).

The participating managers were designated by the corresponding municipal health secretaries. For the purpose of data collection, the managers were approached
Management of basic health units in municipalities of different size: profile and management instruments Carvalho BG, Peduzzi M, Nunes EFPA, Leite FS, Silva JAM 
at the workplace, and the study objectives and instrument were explained to them. Whenever the managers were not at the BHU at the time of the visit, the instrument was given to the municipal health secretary to be returned via the Health Management District internal mail service.

The BHU managers were requested to answer a semistructured questionnaire designed to collect data on their profile and the management instruments they used. Data collection was conducted from July to December 2010. The objective questions were entered twice in software Epi Info version 3.5.1 and then expressed as simple frequencies. Statistical analysis of the data was performed using the chi-squared test; when the probabilistic cell was less than five, Fisher's exact test was used. The significance level was set as $p<0.05$.

The study was conducted following the National Health Council Resolution 466/2012 ${ }^{(6)}$ and was approved by the research ethics committee of the institution with which one of the investigators is affiliated (no. 971/2010). In addition, the study was authorized by the managers of the participating municipalities. All of the participating managers manifested their agreement to participate by signing an informed consent form.

\section{RESULTS}

In the first step managers were allocated into categories and then, the management instruments they used were analyzed and divided into two categories-activities related to the organization of the work process, and activities related to workforce management.

\section{Characterization of Managers}

There is a large predominance of females (96.3\%) without a significant difference between the two groups of municipalities. The age of the managers varied from 22 to 62 years, and the distribution was not homogeneous:
$75.0 \%$ of the managers from small municipalities were younger than 40 years, while $68.1 \%$ of the managers from medium/large municipalities were in the range of 40 years or older $(p<0.0001)$. Most of the managers $(63.9 \%)$ were paid a monthly salary that varied from the equivalent to three and less than seven times the minimum wage (MW) (BRL 510.00 at the time when the study was performed). A significant difference in manager's pay was found between the two municipalities groups, with $92.3 \%$ of the managers from small municipalities being paid less than the equivalent of five times the MW per month, while $66.2 \%$ of the ones from medium/large municipalities were paid the equivalent of five MW's or more per month $(p<0.001)$.

All 108 managers had a higher education degree, with 107 having a nursing degree (99.1\%), and 98 had also earned post graduate degrees $(90.7 \%)$. The managers' educational profile did not differ between the two groups of municipalities. Of the managers with post graduate degrees, 93 managers had attended specialization courses, one had attended a residency program, and four had completed master programs. Most of the managers (60.4\%) reported having had previous managerial experience at another unit; the number of managers with previous experience was greater in the medium/large municipalities $(75.7 \%)$ compared with those in the small ones $(30.6 \%)$ $(p<0.001)$. Most of the managers had been appointed by the municipal health secretary or director in both groups of municipalities (86.7\%).

\section{Activities Related to the Organization of the Work Process}

Regarding the organization of the work process, the following variables were assessed: knowledge of health indicators, knowledge of the goals agreed upon at the municipal level, discussion of these goals with workers, planning of health actions, and evaluation of health actions (Table 1).

Table 1 - Distribution of managers according to the use of instruments for organization of the work process per municipality size, 17 th Health District, Paraná, 2010

\begin{tabular}{|c|c|c|c|c|c|c|}
\hline \multirow{2}{*}{ Management instruments used } & \multicolumn{2}{|c|}{ Small } & \multicolumn{2}{|c|}{ Medium/large } & \multicolumn{2}{|c|}{ Total } \\
\hline & n (36) & $\%$ & n (72) & $\%$ & n (108) & $\%$ \\
\hline \multicolumn{7}{|c|}{ Knows the municipal health indicators ${ }^{a}$} \\
\hline Yes & 28 & 77.8 & 68 & 94.4 & 96 & 88.9 \\
\hline No & 6 & 16.7 & 3 & 4.2 & 9 & 8.3 \\
\hline Ignored & 2 & 5.5 & 1 & 1.4 & 3 & 2.8 \\
\hline \multicolumn{7}{|c|}{ Knows goals and indicators agreed upon } \\
\hline Yes & 32 & 88.9 & 65 & 90.3 & 97 & 89.8 \\
\hline No & 4 & 11.1 & 6 & 8.3 & 10 & 9.3 \\
\hline Ignored & - & - & 1 & 1.4 & 1 & 0.9 \\
\hline \multicolumn{7}{|c|}{ Discusses goals and indicators agreed upon with the unit's workers } \\
\hline Yes & 26 & 72.2 & 60 & 83.3 & 86 & 79.6 \\
\hline No & 6 & 16.6 & 4 & 5.6 & 10 & 9.3 \\
\hline \multirow[t]{2}{*}{ Ignored } & 4 & 11.2 & 8 & 11.1 & 12 & 11.1 \\
\hline & & & & & & Contir \\
\hline $\begin{array}{l}\text { Management of basic health units in m } \\
\text { size: profile and management instrume } \\
\text { Carvalho } B G, \text { Peduzzi M, Nunes EFPA, Leite FS }\end{array}$ & & & & & $\begin{array}{l}\text { Enferm } \\
\text { 48(5):90 } \\
\text { sp.br/ree }\end{array}$ & $Y$ \\
\hline
\end{tabular}




\begin{tabular}{|c|c|c|c|c|c|c|}
\hline ..Continuation & & & & & & \\
\hline \multirow{2}{*}{ Management instruments used } & \multicolumn{2}{|c|}{ Small } & \multicolumn{2}{|c|}{ Medium/large } & \multicolumn{2}{|c|}{ Total } \\
\hline & n (36) & $\%$ & n (72) & $\%$ & n (108) & $\%$ \\
\hline \multicolumn{7}{|l|}{ Plans actions $^{\text {b }}$} \\
\hline Yes & 25 & 69.5 & 66 & 91.6 & 91 & 84.2 \\
\hline No & 7 & 19.4 & 3 & 4.2 & 10 & 9.3 \\
\hline Ignored & 4 & 11.1 & 3 & 4.2 & 7 & 6.5 \\
\hline \multicolumn{7}{|l|}{ Evaluates actions $^{\mathrm{c}}$} \\
\hline Yes & 23 & 63.9 & 58 & 80.5 & 81 & 75.0 \\
\hline No & 12 & 33.3 & 10 & 13.9 & 22 & 20.4 \\
\hline Ignored & 1 & 2.8 & 4 & 5.6 & 5 & 4.6 \\
\hline
\end{tabular}

Results with a statistically significant difference: $a$ Fisher's exact test, $p=0.0304746821 ; b$ Fisher's exact test, $p=0.0105673928 ; c$ Fisher's exact test, $p=0.0221192858$.

A large percentage of managers reported having knowledge of the municipal health indicators (88.9\%), with this percentage significantly lower in the case of the managers from small municipalities $(77.8 \%)$ than in that from the medium/large ones $(94.4 \%)(p=0.03047)$.

A smaller percentage of managers (79.6\%) reported discussing goals and indicators with the unit's workers. The health indicators most frequently mentioned by the managers who answered this question were the child and maternal mortality coefficient, immunization coverage, prenatal care coverage, Pap smear coverage, prevalence of hypertension, diabetes mellitus, tuberculosis and leprosy, and incidence of dengue.

A total of 91 managers (84.2\%) reported planning actions and services. However, their distribution in this regard was not homogeneous, with the percentage of managers from medium/large municipalities (91.6\%) significantly greater than that from the small ones $(69.5 \%)(p<0.01056)$.

Evaluation of routine work actions was reported by $75.0 \%$ of the managers. Additionally, in this case, the percentage of affirmative responses was significantly lower among managers from small municipalities (63.9\%) than that from the medium/large ones (80.5\%) $(p=0.02211)$.

\section{Activities Related to Workforce Management}

The following activities related to workforce management were assessed: staff meetings, performance assessment and healthcare continuing education (HCE) (Table 2).

Almost all the managers reported conducting meetings with the unit staff $(98.1 \%)$. The two managers who reported not conducting staff meetings were from small municipalities. In both groups, the modality of meetings most frequently reported was with the full unit staff $(93.3 \%)$ rather than with representatives (6.7\%). Most of the managers, 64 (59.8\%), reported conducting such meetings every month in both the medium/large (68.7\%) and small (40.0\%) municipalities.

Regarding the assessment of the staff's performance, the responses differed between the two groups of municipalities, as 70 (97.2\%) managers from medium/large municipalities reported conducting performance assessments versus only 14 (38.9\%) managers from small municipalities $(p=0.0000000001)$.
Table 2 - Distribution of managers according to the use of workforce management instruments per municipality size, $17^{\text {th }}$ Health District, Paraná, 2010

\begin{tabular}{lcccccc}
\hline \multirow{2}{*}{$\begin{array}{l}\text { Management } \\
\text { instrument used }\end{array}$} & \multicolumn{2}{c}{ Small } & \multicolumn{2}{c}{ Medium/large } & \multicolumn{2}{c}{ Total } \\
\cline { 2 - 7 } & $\mathbf{n}(\mathbf{3 6})$ & $\mathbf{\%}$ & $\mathbf{n}(\mathbf{7 2})$ & $\mathbf{\%}$ & $\mathbf{n}(\mathbf{1 0 8})$ & $\mathbf{\%}$ \\
\hline Staff meetings & & & & & & \\
Yes & 34 & 94.4 & 72 & 100.0 & 106 & 98.1 \\
No & 2 & 5.6 & - & - & 2 & 1.9 \\
Ignored & - & - & - & - & - & - \\
\hline Performance assessment $^{\mathbf{a}}$ & & & & & \\
Yes & 14 & 38.9 & 70 & 97.2 & 84 & 77.8 \\
No & 18 & 50.0 & 1 & 1.4 & 19 & 17.6 \\
Ignored & 4 & 11.1 & 1 & 1.4 & 5 & 4.6 \\
\hline Continuing education & & & & & & \\
Yes & 21 & 58.3 & 62 & 86.1 & 83 & 76.9 \\
No & 15 & 41.7 & 8 & 11.1 & 23 & 21.3 \\
Ignored & - & - & 2 & 2.8 & 2 & 1.8 \\
\hline
\end{tabular}

Results with a significant difference: a Fisher's exact test, $p=0.0000000001$; bFisher's exact test, $p=0.0005567579$

In addition, the performance of HCE activities with staff was significantly different between the two groups of municipalities. Performance of such activities was reported by $86.1 \%$ of the managers from medium/large municipalities versus $58.3 \%$ of the managers from small municipalities $(p=0.00055)$.

\section{DISCUSSION}

Female gender was strikingly predominant in the present sample, corresponding to $96.3 \%$ of the managers; this finding is in accordance with the results of other studies $^{(6,10,13)}$.

The fact that the managers were overall older in the medium/large municipalities may indicate that younger professionals or those at the beginning of their careers, had less opportunities to be appointed to this position at such BHUs, while the opposite may be the case in small municipalities, where the turnover of nurses who assume managerial positions may be greater. These findings depict a situation quite different ${ }^{(13)}$ from the one at private institutions, which exhibit a tendency to hire young professionals trained to implement processes of organizational innovation and where particular value is attributed to characteristics such as managerial knowledge 
and capacity for innovation and productivity. By contrast, public healthcare institutions are usually characterized by an adherence to traditional managerial rules and development of rigid professional careers.

The difference found in the managers' salaries between the two groups may be a result of the younger professionals from the small municipalities being at the beginning of their careers. In addition, the career and salary plans are more soundly established at medium and large municipalities.

Although other studies also found a predominance of nurses among the managers of BHUs at various Brazilian municipalities, ${ }^{(6,10,12)}$ in none was it as expressive as the one found in the municipalities investigated in the present study. The participation of nurses in management, including in the $B C$ setting, is quite significant in Brazil, ${ }^{(10,14-15)}$ in contrast to Europe and, more particularly, the English National Health System (NHS), where community-based nurses have a significant presence in the management of palliative care, chronic diseases and health education in the primary care setting ${ }^{(16)}$. Despite such predominance of care-related tasks, the work of nurses also influences changes in public healthcare services and policies in England ${ }^{(16)}$.

The significant participation of nurses in the management of healthcare services in Brazil points to the commitment to the health of individuals and the community, given their function in the promotion, protection, recovery and rehabilitation of health and their quest to interfere in the relationship between human beings and their environment throughout life, ${ }^{(14)}$ in addition to their well-acknowledged administrative training ${ }^{(13,15)}$ and satisfactory interactions with the remainder of the members of multi-professional staffs ${ }^{(13)}$. However, nurses working in management perform their tasks in a technically and politically homogenous manner, being unable to break with the traditional institutional models that have long shaped the work process in healthcare, ${ }^{(9)}$ characterized by the priority given to following orders and preserving the status quo ${ }^{(13)}$.

Regarding the exercise of leadership among nurses, one study ${ }^{(17)}$ showed its current evolution in the United Kingdom and the need of that leadership role to meet the future changes in the NHS. However, the author considers the complexity inherent in the leadership function, which is under the influence of several factors in the NHS, including organizational culture, emotions, intelligence and knowledge of sociopolitical and gender-related matters. Nurses tend to be more passive in their exercise of leadership and may be considered a group traditionally oppressed by the male medical dominance ${ }^{(17)}$. A literature review on the styles of leadership and corresponding effects on workforce management and the work environment indicates that the leaders who focus on their interaction with individuals, rather than on tasks, achieve the best results ${ }^{(18)}$.
Concerning the use of management instruments for the organization of the work process, the managers were reported to have satisfactory knowledge of health indicators and to perform planning and assessment of actions. It is worth observing that the large percentage of managers who reported having knowledge of health indicators may be attributed to the large coverage rate of the Family Health Strategy in the municipalities assessed (close to $100 \%$ in the small municipalities and over $50 \%$ in the medium and large ones). To detect the users' needs and epidemiological risks, the Brazilian Health Ministry recommends that family health teams should have accurate knowledge of the indicators of morbidity and mortality in their corresponding area of activity. Such indicators should also serve as one of the references for the organization and evaluation of the routine work process ${ }^{(2)}$.

The indicators most frequently mentioned by the managers are related to the areas defined as BC priorities in the agreed Guidelines, Aims, Goals and Indicators included in the Brazilian Health Ministry's computerized monitoring system, the SISPACTO ${ }^{(19)}$. However, a smaller percentage of managers (79.6\%) reported discussing these goals and indicators with the workers at the corresponding units. That approximately $20 \%$ of the managers did not discuss the agreed indicators and goals with the unit staff may indicate that the managers make very little or no use at all of the results of information in the decision-making process and that the participation of the staff in the organization of the work process is quite scarce. For managers to make use of health information in their work process, they first need to be acquainted with and know how to use information systems, which is not always the case $^{(20)}$. Another factor that hinders the use of health indicators is that the information systems are not yet fully integrated into the actual lines of intervention; thus, even when the information is available, many managers do not know what to do with $i t^{(5)}$. Thus, it is crucial for information to be easily located and accessible and to provide elements for the construction of the explanatory chain of problems exhibited by the healthcare system or the corresponding geographical area ${ }^{(20)}-$ i.e., it may supply grounds for the planning and evaluation of actions.

It is a consensus among the specialists in the health field that planning is an organizational tool that is a part of the development of organizations and aims to orient actions to achieve results and pre-established goals. The implementation of planning is a management assignment; thus, it should be included within the management of services $^{(7-8,10-11,21)}$. The results of the present study suggest that this conception is supported by most of the managers studied because $84.2 \%$ of them reported planning actions as a part of their routine.

If planning is used to ground the development of health actions and services, it should be closely linked to an information system allowing the accurate identification of the problems in a given geographical area ${ }^{(10)}$ as 
well as to an evaluation proposal to monitor its development and indicate the need to periodically review the planning of actions ${ }^{(15)}$.

Although the importance of assessing the management of healthcare as a support tool for decision making is acknowledged in the SUS environment, as well as its use for the evaluation of the impact of actions and services on the state of health of a population, such a managerial tool is scarcely applied to the routine work process and is not used in its full potential ${ }^{(15)}$. This analysis corroborates these findings especially regarding the small municipalities.

Approximately $88.9 \%$ of the managers who participated in the present study reported having knowledge of the local health indicators, $84.2 \%$ reported planning actions, and $75 \%$ reported evaluating them. Thus, it is possible to infer that not all managers investigated succeed in establishing connections among the identification of problems and the planning and evaluation of actions in their managerial routine. This situation is even more worrisome in the small municipalities because the percentages of managers who reported knowing the local health indicators and planning and evaluating health actions were $77.8 \%, 69.5 \%$ and $63.9 \%$ respectively. These results may indicate the effect of the scarce professional experience of those managers, a lack of planning structure, and low managerial capacity in those municipalities. According to the Master Plan for Small Municipalities, ${ }^{(22)}$ this situation points to the need to put in place specific policies for this type of municipality. The findings of the present study corroborate those of other studies that indicate that in the planning of actions, the organizational culture and social context that encompass the planning process should be considered ${ }^{(21)}$.

Regarding the use of instruments for work organization, the large percentage of managers who reported holding meetings including all the staff in the units indicates the high value attributed to this space for communication within the context of the work process at the investigated BHUs. This practice-i.e., the availability of a space for collective discussion of work-may contribute to the promotion of participation in the planning of health actions, incentives of the staff to perform collaborative work, and an increase of the potential of interaction among workers and their various professional fields, aimed at the provision of comprehensive healthcare ${ }^{(23)}$.

Despite the importance of staff meetings, those same authors call the attention to fact that the availability of such a space of communication by itself is not enough to ensure the engagement of workers or the development of joint, integrated and collaborative work; additionally, how that space is used is crucial in this regard. Staff meetings may represent a space for participation and communication, in which the social interactions seek to promote a mutual understanding among the participating individuals, being understood as a communicative practice aimed at the collective production of care. Alternatively, staff meetings may represent a space purely devoted to information, expressing a monologic action, and being used as an instrument to ensure the functioning of services, without considering the specificities inherent to the work process in healthcare or the necessary discussion of the intended results of the care provided ${ }^{(23)}$.

In the remainder of the managerial activities targeting the workforce-namely, performance evaluation and HCE actions - the greatest weakness was evidenced by the managers from small municipalities, as only $38.9 \%$ and $58.3 \%$ of them reported performing such activities respectively.

Evaluation of workers is one of the responsibilities of managers; evaluations allow for the workers to have an idea of their own performance and for the institutions to implement the type of training and competencies needed to achieve their goals ${ }^{(24)}$. Assessment of worker performance started to be systematically applied since the emergence of Taylorism for the purpose of disciplining workers. During the course of the $20^{\text {th }}$ century, the assessment of workers was improved because of the contribution of the social sciences, whereby the need of organizations for instruments to induce workers to adopt or strengthen particular attitudes began to be considered ${ }^{(25)}$. For these authors, to evaluate means in a few words, to compare the results actually obtained with the planned ones, and presupposes the existence of some mechanism of monitoring that allows for the correction of deviations. They also observed that evaluating work performance is quite complex; it is not merely the result of the skills intrinsic to individuals but also of interpersonal relationships, the work environment, and the characteristics of organizations ${ }^{(25)}$.

The systematization of performance evaluation is crucial for it to achieve its goals for both workers and institutions. However, the results of the present study indicate that such systematization is not routine in the investigated BHUs and, more particularly, in the case of the small municipalities, most likely as a consequence of their lesser organizational capacity and poorer work management structure.

HCE is an educational process triggered by discomfort perceived in routine activities that should be addressed to transform the present conditions of the work process in healthcare ${ }^{(26)}$. Engagement of staff members is crucial for building knowledge relevant to coping with the demands posed by the routine at the BHU.

The activities related with work management-i.e., HCE and performance evaluations-are closely related to the organizational culture. However, the implementation of those activities does not only depend on the intentions of the managers of BHUs alone but also on the organization as a whole, whenever the mission of the organization attributes high value to immaterial investment (on people) and to the participation of its members and the atten-
Management of basic health units in municipalities of different size: profile and management instruments Carvalho BG, Peduzzi M, Nunes EFPA, Leite FS, Silva JAM 
tion paid to them. These are the basic assumptions of a novel paradigm, according to which organizational listening should be integrated with a project of communication and a new model of managerial leadership able to mobilize workers instead of being strong and charismatic ${ }^{(27)}$. In this regard, the results of the present study inferred that the organizational culture and processes are less developed at the small municipalities.

\section{CONCLUSION}

Regarding the managers' profile, gender distribution and characteristics relative to professional training were similar in both types of municipalities assessed: most of the managers were female and nurses and had attended graduate courses. Expressive differences were detected relative to their age, salary and managerial experience.

The managers demonstrated that they make considerable use of instruments for the organization of the work process and work management. Nevertheless, the proportion of managers from small municipalities who reported using such instruments was smaller. This finding may be due to the lesser managerial experience of that group of managers, a lack of institutionalization of several such instruments at the corresponding municipalities, and charac- teristics specific to small municipalities, including a lack of planning structure and poor managerial capacity. These results are important because, although the small municipalities have a low population density, their spatial capillarity is large, as they represent $80 \%$ of the municipalities in the region investigated. In addition, the organization of the production of health goods and services and results achieved at the individual and collective levels are impaired in the small municipalities, making their operational capacity to elaborate and coordinate healthcare networks quite fragile, as such a function corresponds to the local BC level.

To overcome the problems detected in the present study, more effective participation at the state and federal levels is recommended to support the small municipalities, with strategic activity in matters related to work management at the SUS, such as the formulation of policies to guide the managerial activity and training of managers.

To conclude, the present study gathered important information to contribute to the knowledge and analysis of the profile of managers of BHUs at the two groups of municipalities investigated and their use of management instruments. Further studies aimed at a more thorough assessment of the hindrances posed to managers-in particular concerning the implementation of such instruments-are recommended.

\section{REFERENCES}

1. Vasconcelos CM, Pasche DF. O Sistema Único de Saúde. In: Campos GW, Minayo MCS, Akerman M, Drumond Junior M, Carvalho YM, organizadores. Tratado de saúde coletiva. São Paulo: Hucitec; 2006. p. 531-62.

2. Brasil. Portaria n. 2.488, de 21 de outubro de 2011. Aprova a Política Nacional de Atenção Básica, estabelecendo a revisão de diretrizes e normas para a organização da Atenção Básica, para a Estratégia Saúde da Família (ESF) e o Programa de Agentes Comunitários de Saúde (PACS). Diário Oficial da União, Brasília, 24 out. 2011. Seção I, p.48-55.

3. Brasil. Portaria № 4.279, de 30 de dezembro de 2010. Estabelece as diretrizes para a organização da Rede de Atenção à Saúde no âmbito do Sistema Único de Saúde (SUS). Diário Oficial da União, Brasília, 31 dez. 2010. Seção 1, p. 89.

4. Mishima SM, Villa TCS, Silva EM, Gomes ELR, Anselmi $M L$, Pinto IC, et al. Organização do processo gerencial no trabalho em saúde pública. In: Almeida MCP, Rocha SM, organizadores. O trabalho de enfermagem. São Paulo: Cortez; 1997. p. 251-96.

5. Campos GWS. Subjetividade e administração de pessoal: considerações sobre modos de gerenciar o trabalho em equipes de saúde. In: Merhy EE, Onocko R, organizadores. Agir em saúde: um desafio para o público. 3 a ed. São Paulo: Hucitec; 2007. p. 229-66.
6. Fernandes LCL, Machado RZ, Anschau GO. Gerência de serviços de saúde: competências desenvolvidas e dificuldades encontradas na atenção básica. Ciênc Saúde Coletiva. 2009;14 Supl.1:1541-52.

7. Vanderlei MIG, Almeida MCP. A concepção e prática dos gestores e gerentes da estratégia de saúde da família. Ciênc Saúde Coletiva. 2007;12(02):443-53.

8. Felli VEAF, Peduzzi M. O trabalho gerencial em enfermagem. In: Kurcgant $\mathrm{P}$, coordernadora. Gerenciamento em enfermagem. 2ª ed. São Paulo: Guanabara Koogan; 2010. p. 1-13.

9. Trevizan MA, Mendes IAC, Hayashida M, Godoy S, Nogueira MS. The search for attitudinal commitment: tendency in the manager nurse's ethical behavior. Rev Esc Enferm USP. 2009;43(3):721-5.

10. Fernandes MC, Barros AS, Silva LMS, Nóbrega MFB, Silva MRF, Torres RAM. Análise da atuação do enfermeiro na gerência de unidades básicas de saúde. Rev Bras Enferm. 2010;63(1):11-5.

11. Protti ST, Silva LMC, Palha PF, Villa TCS, Ruffino Neto A, Nogueira JA, et al. Managing the Basic Health Unit in tuberculosis control: a field of challenges. Rev Esc Enferm USP. 2010;44(3):665-70. 
12. Programa das Nações Unidas para o Desenvolvimento (PNUD). Atlas de Desenvolvimento Humano no Brasil, 2013 [Internet]. [citado 2014 jul. 12]. Disponível em: http://www. pnud.org.br/

13. Alves M, Penna CMM, Brito MJM. Perfil dos gerentes de unidades básicas de saúde. Rev Bras Enferm. 2004;57(4):441-6.

14. Melo CMM, Santos TA. A participação política de enfermeiras na gestão do sistema único de saúde em nível municipal. Texto Contexto Enferm. 2007;16(3):426-32.

15. Chaves LDP, Tanaka OY. Nurses and the assessment in health system management. Rev Esc Enferm USP. 2012;46(5):1274-8.

16. Cross S. The future: a primary care-led NHS. Br J Community Nurs. 2010;15(4):177-8.

17. Sherring S. Nursing leadership within the NHS: in evolutionary perspective. Br J Nurs. 2012;21(8):491-4.

18. Cummings GG, MacGregor $T$, Davey $M$, Lee $H$, Wong $C A$, Lo $\mathrm{E}$, et al. Leadership styles and outcome patterns for the nursing workforce and work environment: a systematic review. Int J Nurs Stud. 2010;47(3):363-85

19. Brasil. Ministério da Saúde; Secretaria de Gestão Estratégica e Participativa. Caderno de diretrizes, objetivos, metas e indicadores - 2013/2015: orientações para o processo de pactuação. Brasília; 2013.

20. Pinheiro ALS. Gerência de enfermagem em unidades básica: a informação como instrumento para a tomada de decisão. Rev APS. 2009;12(03):262-70.
21. Rivera FJU, Artmann E. Planejamento e gestão em saúde: flexibilidade metodológica e agir comunicativo. In: Rivera FJU. Análise estratégica em saúde e gestão pela escuta. Rio de Janeiro: Fiocruz; 2003. p. 17-35.

22. Brasil. Ministério das Cidades; Secretaria Nacional de Programas Urbanos. Plano Diretor em Municípios de pequeno porte [Internet]. [citado 2011 ago. 28]. Disponível em: http://portal.cnm.org.br/sites/8800/8875/download/2_dia/ PlanoDiretoremMunicipiosdepequenoporte_Modificada.pdf

23. Peduzzi M, Carvalho BG, Mandu ENT, Souza GC, Silva JAM. Trabalho em equipe na perspectiva da gerência de serviços de saúde: instrumentos para a construção da prática interprofissional. Physis Rev Saúde Coletiva. 2011;21(2):629-46.

24. Marquis BL, Huston CJ. Administração e liderança em enfermagem: teoria e prática. Porto Alegre: Artmed; 2010.

25. Brandão HP, Guimarães TA. Gestão de competências e gestão de desempenho: tecnologias distintas ou instrumentos de um mesmo construto? Rev Adm Empresas. 2001;41(1):8-15.

26. Ceccim RB. Educação permanente em saúde: descentralização e disseminação de capacidade pedagógica na saúde. Ciênc Saúde Coletiva. 2005;10(4):975-86.

27. Rivera FJU. Cultura e liderança comunicativa. In: Rivera FJU. Análise estratégica em saúde e gestão pela escuta. Rio de Janeiro: Fiocruz; 2003. p. 185-218. 